The Dhaka University Journal of Linguistics: Vol. 2 No.4 August 2009 Page: 59-91, Published on August 2010 by the Registrar, Dhaka University ISSN-2075-3098

\section{Identifying The English Language Needs of Humanities Students at Dhaka University}

\author{
Dr. Tazin Aziz Chaudhury ${ }^{1}$
}

1. Assistant Professor Dept. of English DU

Email : tazinchaudhury@yahoo.com

\begin{abstract}
Till recently freshmen at all the departments of the Faculty of Humanities of Dhaka University compulsorily attended a centrally conducted English language skills development course titled the English Foundation Course. Since 2006 the Foundation Course was discontinued and replaced by individual courses conducted by the respective departments. However neither the English Foundation Course nor the present individual courses were designed on the basis of Needs Analysis - the primary pre-requisite of any curriculum design nor have they ever been evaluated. This article presents the findings of a formal needs analysis and evaluation conducted by the researcher.
\end{abstract}

Key Words: Needs Analysis; Evaluation; Language skills and sub-skills; Course usefulness and difficulty; Classroom teaching style;

\section{Introduction}

Global literacy skills namely proficiency in technology and English, have effected globalization; which has profoundly impacted the political, socio-economic and cultural dimensions of our societies (Harvey, 1990). In response to changes wrought by globalization all countries are attempting to ensure the adequate equipment of global literacy skills. Because of political \& historical reasons and its worldwide use in different domains such as international communication (Kennedy, 2001); business, scientific discourse, travel, education and media (Manivannan, 2006); English has become the de facto lingua franca of international communication and a much sought after commodity (Crystal, 2003; Phillipson \& Skutnabb-Kangas, 1999). Participation in the global economy has led to "an explosion" of foreign investments in most former colonies and has opened up job opportunities where English competency is a prerequisite for employment (Tsui \& Tollefson, 2007).

Keen to participate in the global economy Bangladesh a nation struggling against poverty and illiteracy has opened up to the rest of the world. English is part of Bangladesh's colonial heritage; the language of the educated elite and not commonly used in daily interaction, yet the contemporary labor market particularly the corporate world needs a work force competent in English.

"Within the country, employment in any organization looks for proficiency in English. Entry into government jobs requires being selected through a competitive examination where English is a subject, while any non-government office that has dealings outside the national border looks particularly for people with English proficiency. Since the pay structure of such NGO's is better than other jobs, people are interested to be employed there, and want to learn English." (Qader, 1999:187)

Post-independence English was de-emphasized in education and replaced by Bangla in all official domains. Books were translated into Bangla to meet the demands of universities; as a result English standards fell to abysmal depths in public schools and universities (Choudhury, 2001). However almost 95\% of the texts and reference books are in English, thus Bangla has failed to become an adequate medium for higher education (Banu \& Sussex 2001b); this has resulted in the necessity of giving time, attention and energy to the learning of English (Alam, 2001).

Given the crucial demands for English at the workplace, public universities have to comply with the demands of industry if they want their graduates to be employable. In order to improve the English proficiency of local graduates; compulsory EAP courses 
have been implemented in the freshman year in all public universities from the 1994-95 academic sessions, in accordance with the Ministry of Education and the University Grants Commission's instructions. Fearing marginalization Bangladesh is faced with the grim reality of lagging behind neighboring countries which are forging ahead in terms of access to the world market. In a stance of "pragmatic liberalism", English has been accepted as a modern-day asset, and is considered to be of key importance to national development and social and economic advancement (Rahman, 2007).

\section{Statement of the Problem}

In Bangladesh, English Language experts design English Language courses for both the private and public sectors. Time and again the experts construct and mould new course outlines tailored to meet the diverse language learning needs of their learners. Often they are pressed for time and have to prepare and introduce these courses within specified deadlines, because of which, very often there is not enough time to do proper needs analysis before designing and implementing these courses. Once implemented, the courses are never evaluated by the authorities concerned. Constraints, problems, limitations of students and teachers have never been acknowledged or explored. Not surprisingly in spite of compulsory English teaching for a whole academic year, the general standard and levels of proficiency in the students' English leave much to be desired. Therefore there is a need to identify the specific English language needs of the students and the teachers at Dhaka University and specify the content of the English courses based on these needs. This study focuses on identifying the specific English language needs of the students and teachers, of the different departments of the Faculty of Arts of Dhaka University and gauges the effectiveness of the current English courses.

\section{Theoretical Framework}

\section{Needs Analysis: A Definition}

The ESP field developed in tandem with the concern for learners' needs, which are an important factor in deciding course objective.

The Dhaka University Journal of Linguistics
The method of identifying learners' needs is termed Needs Analysis (NA). NA is a prominent feature and vital element in designing any ESP syllabus (Munby, 1978; Robinson, 1991). NA serves as the tool for identification and justification for an ESP course. NA helps identify the specific language needs that can be addressed in developing goals, objectives, and content for a specific language program. According to Hutchinson and Waters (1987), NA is the irreducible minimum of an ESP approach to course design'. The primary goal is to determine the content for an appropriate English language course where all decisions as to content and methodology are based on learners' reasons for learning. Therefore a NA to identify the specific needs of the target learners should be conducted before determining the outline and syllabus content of an ESP course. Gardner and Winslow (1983) affirm that the need to conduct a NA is "to produce information which acted upon makes a course better adapted to students' needs" (Gardner and Winslow cited in Dudley-Evans \& St John, 1998:121). Dudley-Evans \& St John (1998) summarized NA simply as the process of establishing the 'what' and 'how' of a course. This definition is extremely brief and does not provide a better insight into what exactly is involved in the 'process' and aspects of 'what' and the 'how'. Brindley (1984) however provided a clearer explanation by identifying NA as a set of tools, techniques and procedures for determining the language content and learning process for specified groups of students. Nunan consolidated these two definitions by classifying NA into two processes: 1) content needs: included linguistic / lexical / discourse selection and sequencing of topics, grammar, functions, notions and vocabulary 2) process needs: referred to the selection and sequencing of learning tasks, experiences and strategies to be used by students and teachers.

In the local scenario several Bangladeshi researchers and curriculum experts lamented the lack of any comprehensive and tangible data on the needs of Bangladeshi, tertiary level learners. In this regard some researchers strongly recommended that a NA be conducted at Dhaka University and elsewhere at other Bangladeshi universities. Khan (2000) evaluated the English Foundation Course being used at the Humanities faculty of Dhaka University and concluded that:

Vol. 2 No. 4, August 2009 
"the syllabus needs to be revised and developed -- the content of the syllabus needs to be outlined clearly -- the current syllabus does not specify course objectives -- the contents of the syllabus need to be rewritten keeping in mind the needs and demands of the students. -- before revising the syllabus a needs analysis could also be carried out to determine student needs" (Khan, 2000:106-7).

Similarly Haque \& Zaman (1994) recommended a NA on the basis of their investigations into the language learning motivation, and anxiety of Bangladeshi tertiary level learners learning English. Haque \& Zaman (1994) declared that

"the EFL course should aim at academic purposes and learner needs/wants as -- the learners' needs and wants tremendously control the whole package of teaching materials, aids and equipment, and the application of teaching techniques and strategies, the employment of classroom activities and, most importantly, the method of teaching and the construction of the syllabus" (Haque \& Zaman 1994:79).

More recently Rahman (2007) articulated that

"the syllabus needs to be revised and developed ... the content of the syllabus needs to be outlined clearly ... the current syllabus does not specify course objectives ... the contents of the syllabus need to be rewritten keeping in mind the needs and demands of the students ... before revising the syllabus a needs analysis could also be carried out to determine student needs", (Rahman, 2007:226).

Despite the importance of conducting a NA to ensure that specific language needs are addressed, Widdowson (1984) criticized NA as an attempt to atomize teachers' series of discrete skills, leading to limited communicative repertoire. Nunan (1999:155) agreed with Widdowson and elucidated that NA:

1) develops generalized capacities in learners;

2) achievement would depend more on methodology (how instructions are done) than syllabus design (specification of content);

3) does not often cater for learners ability or inability to transfer skills learnt in the classroom to other situations and solve the unpredictable real communication problem outside the classroom.

Thus NA should be treated as a guide and not as a blue print in providing direction towards the recommendations of a course design. NA is not a be-all end-all activity rather it is a continuing process in which conclusions drawn are constantly checked and reviewed as Dudley-Evans \& St John (1998:127) rightly put it "we need information that will help us select and prioritize" during the NA stage and when meeting with the target learners.

Flowerdew and Peacock (2001) suggested data be collected from the people responsible for the course, i.e. language teachers, the subject matter expert, the learners, the administrators and the institution. This ensures a balanced view of the course.

Jordan (1997) suggested 14 methods of data collection:

1) Advance documentation

2) Language tests at home

3) Language tests on entry

4) Self-assessment

5) Observation and monitoring

6) Class progress test

7) Surveys

8) Structured interviews

9) Learner diaries

10) Case studies

11) Final tests

12) Evaluation or feedback

13) Follow-up investigation

14) Previous research (cited in Flowerdew and Peacock, 2001)

Robinson (1991) recommended questionnaires, interviews, observations, case studies, test and authentic tests. Flowerdew and Peacock (2001) added learners' diaries and teachers' notes to the list.

Evaluation is a necessary part of NA; Weir and Roberts (1994) observed that - 
Evaluation is a part of the whole educational process, specially, in ELT that seeks to improve the educational quality of language program or project normally while it is in progress (Weir and Roberts, 1994:4)

Evaluation provides the means for determining whether any program is meeting its goals; that is, whether, the measured outcomes for a given set of instructional inputs match the intended or pre-specified outcomes i.e. evaluation is carried out to see whether the stated objectives have been achieved. Similarly Tuckman (1985:3) opined that:

"how successfully the language program innovations are being implemented can only be observed by a systematic evaluation procedure"

So Evaluation is integral to professional practice; research conducted on various ELT programs or projects have shown how systematic evaluation generates relevant data and information about the program's innovation or whether changes need to be made in the course outline and the selected materials and how far it can be continued or whether it is transferable etc. The whole educational process that is the refining an ELT program cannot be completed without a methodical evaluation procedure.

The main purposes of evaluation in language education projects and programs are for accountability or developmental purposes, or closely linked to the concept of awareness raising (Rea-Dickins and Germaine, 1998). Norris (1990 as referred to in Ellis, 1998) identified two broad purposes for program evaluation. The evaluation may be based on an "objectives model" i.e. evaluation carried out to see how far objectives have been met; or a "developmental model"- evaluation done for developmental purposes, to identify strengths and weaknesses of the design and methodological procedures or both (Norris, 1990). One of the objectives may be to arouse awareness for "professional development" among individuals involved with the responsibility for the educational program (Rea-Dickins and Germaine, 1998). So evaluation concerns managers and key staff members for gathering valuable information and knowledge to inform them in decision making and taking steps for making various developments within the curriculum.

\section{Review Of Related Research}

Khan (2000) in her evaluation of the English Foundation Course which was being taught to students of thirteen departments at the Arts Faculty at Dhaka University found that:

'students realized that English has the status of an international language and believed that there was no alternative to English and hat is why the demand for English is increasing all over the world. They were also aware of the importance of English for the future and admitted that a) English is a pre-requisite for getting good jobs b) for being successful in competitive examinations (e.g. BCS (Bangladesh Civil Service Exams)) and c) for career development d) for accessing higher education books e) and, in general, indispensible for communicating with the outer world. English is essential to give access to academic texts and for communication' (Khan, 2000:95).

Her findings on students' views on the course were that:

'the majority of the students think that the course was useful only to a certain extent because all their expectations were not fulfilled. Students expressed their disappointment that hardly any work on 'listening' and 'speaking' was done in class and as a result their 'speaking skills' have not improved - a few students stated their grammatical abilities had improved - they were not fully satisfied with their textbook - they want the duration of the course to be extended - they pointed out the need for more classes on 'speaking' and 'writing.' They also suggested smaller classes, individual attention, and separate course for 'speaking' in second year and different textbooks for different departments' (Khan, 2000:95-6).

The implications and suggestions for curriculum development made on the basis of her study were:

'the syllabus needs to be revised and developed - the content of the syllabus needs to be outlined clearly -appropriate methodology should also be specified. The current syllabus does not specify course objectives or methodology. The contents of the syllabus need to be rewritten keeping in mind the needs and demands of the students --- the emphasis on grammar in the current course may be reduced the course needs to focus on the importance of the four skills -

Vol. 2 No. 4, August 2009 
an integrated approach could be adopted -- curriculum designers should understand discuss and outline the content of the syllabus --- "before revising the syllabus a needs analysis could also be carried out to determine student needs." (Khan, 2000:106-7)

Dooey (2006) identified the listening and speaking needs of international students at Curtin University in her NA and included both ESL instructors and students in the study. The perceptions of students and instructors differed to some degree but they agreed on the importance of listening for academic success and attributed importance to general listening skills in lectures, tutorial and group assignments and areas of difficulty were also identified.

Basturkmen and Al-Huneidi (1996) studied the English needs students and faculty in Kuwait University to examine perceptions of the importance of skills, sub-skills, and language deficiencies; language demands and needs. Perceptions of students and faculty differed on the importance of reading and listening and areas of difficulty and specific tasks important for study were identified; the relevance of the institutions' current English second language program was assessed. It was found that over $60 \%$ faculty members perceived students to have inadequate skills.

Akin and Guceri (2001) carried out a materials evaluation at Turkey's Bilkent University. New course outlines and materials for EAP/EOP task-based syllabus had been designed and produced on the basis of a NA. Feedback on the effectiveness of the new materials found that the materials were unsatisfactory; lecture-based and theoretical and not task-based; and text selection was random. Based on this evaluation improvement plans for producing more effective materials were adopted.

Zhu \& Flaitz (2005) conducted a NA with students and faculty at a public university in the United States. They found that undergraduates faced difficulties with listening to long lectures, juggling listening and note-taking, discussions, extensive reading, comprehension of information, application of reading strategies, the amount of reading assigned, having to simultaneously read and listen, and the slow reading pace. The need to produce academically acceptable writing; participating in discussions, interaction in and out of class was hard. They feared making grammatical mistakes while speaking, or asking wrong questions. Faculty perceived the students' difficulty and considered them weak in speaking and writing but average in listening and reading.

The findings of the present research reflected and confirmed different strands of the findings from all the aforementioned studies.

\section{Methodology}

A computer coded questionnaire using a five-point measurement scale to assess responses to close-ended questions was used to determine the students' and teachers' perceptions. The completed questionnaires were analyzed using SPSS software. For easy reference the data has been presented in table form and frequency counts and percentages have been used to describe the findings and data analyses.

- Questionnaires were given to 60 second year students from the Departments of History, Philosophy and Linguistics at the Humanities Faculty of Dhaka University in the 2006-2007 academic session.

- Corresponding questionnaires were given to 30 subject teachers from these departments.

- Classroom observation was also used to clarify questionnaire findings

Overview of Skills Needed and Difficulties Encountered

The Humanities students' perceptions regarding the four language skills are presented in this section.

\section{Frequency of use of the language skills}

The findings for frequency of use of the four skills are presented in Figure 1

Vol. 2 No. 4, August 2009 


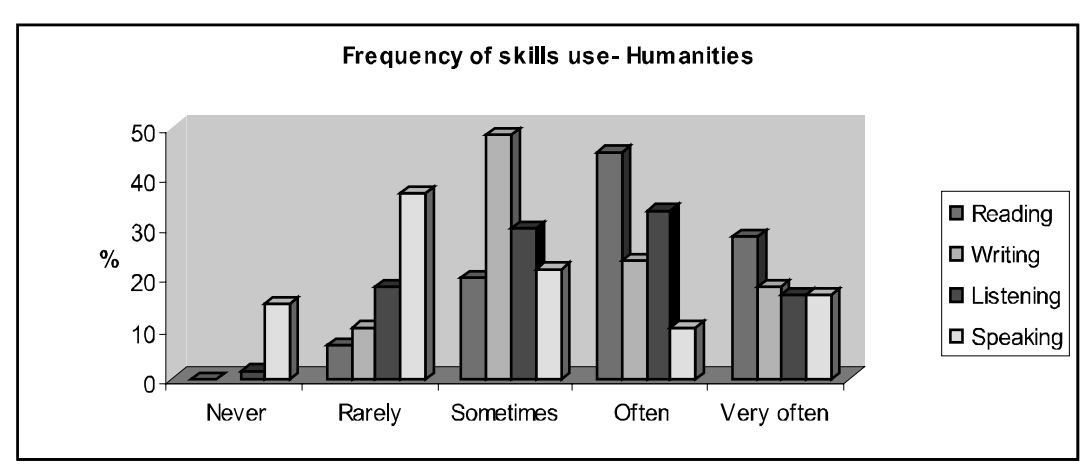

Figure 1: The frequency that the participants are expected to use English skills in their course of study

Significantly:

- $>50 \%$ students "rarely - never" speak \& $>25 \%$ "often - very often" speak

- $50 \%$ "often - very often" listen \& $20 \%$ "rarely - never" listen

- $>70 \%$ "often - very often" read $20 \%$ sometimes read

- $>40 \%$ "often - very often" write \& $48.3 \%$ "sometimes" write

The low frequencies obtained for speaking and writing may be attributed to the fact that the medium of instruction at the Humanities Faculty is predominantly Bangla. Hence the students do not have to speak or write in English; however most texts are in English and most lecturers frequently code switch which may account for the higher frequencies for reading and listening. The findings were also corroborated by classroom observation.

\section{Difficulty faced in the language skills}

The difficulty students faced whilst using the language skills are summarized in Figure 2.

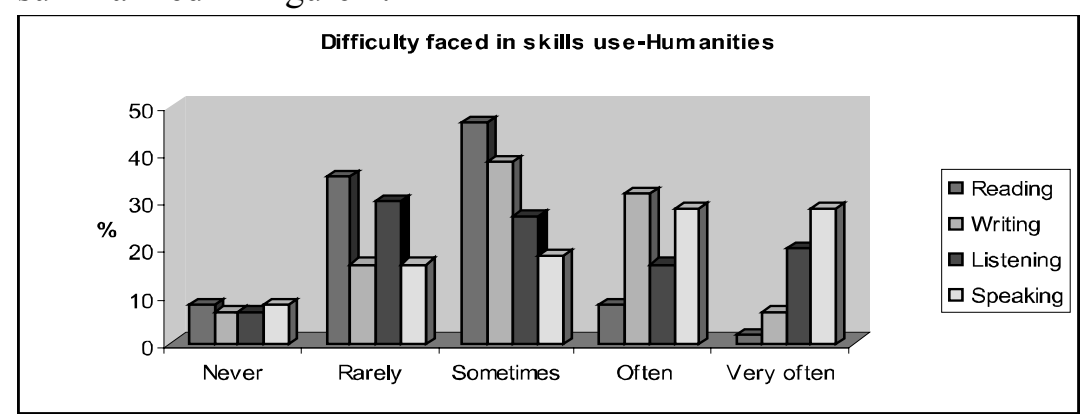

Figure 2: The frequency of difficulty faced by students in using the English language skills

The Dhaka University Journal of Linguistics
Notably:

- $>40 \%$ "rarely - never" had difficulty reading; $10 \%$ "often - very often" did \&

$>45 \%$ "sometimes" did

- $>40 \%$ "rarely" or "never" had difficulty writing, $38.4 \%$ often very often" \& $38.3 \%$ "sometimes" did

- Equal numbers 36.7\% "rarely - never" \& "often - very often" had difficulty listening; and 26.7\% "sometimes" did

- $>55 \%$ "often - very often" had difficulty in speaking \& $18.3 \%$ "sometimes" did \& 25\% "never - rarely" did

The findings on the whole indicate that all the skills are difficult for the Humanities students. These findings have been somewhat corroborated by the teachers' findings.

\section{Perceived importance of the skills for academic success}

The students' opinion of the importance of the English language skills for their academic success is disclosed in Figure 3.

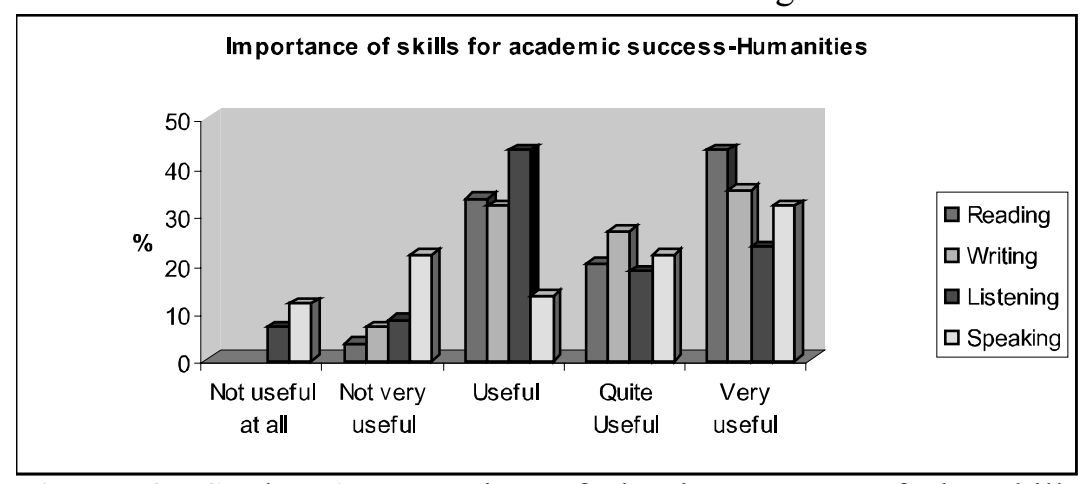

Figure 3: Students' perception of the importance of the skills in relation to academic success

It was found that:

- majority (66.7-96.6\%) felt all skills are "important" for academic success.

- $33.4 \%$ felt speaking "not important"

- $15 \%$ felt listening "not important".

The medium of instruction in this Faculty is Bangla with some intermittent English phrases; and the lecture mode of teaching is mostly used (95\%), where students do not need to speak much. So 
based upon their classroom experience some students perceive listening and speaking as not important for their academic success. The teachers' findings contradict this as all the teachers $(100 \%)$ perceived all the skills as important for their students' academic success. Similarly Khan (2000) found that students assigned more importance to speaking and writing for their academic success.

\section{Teachers' perception of students' proficiency in the four skills}

The findings for the teachers' perceptions of their students' proficiency in the four skills based on their evaluation of students' class performance and written assignments are presented in Figure 4.

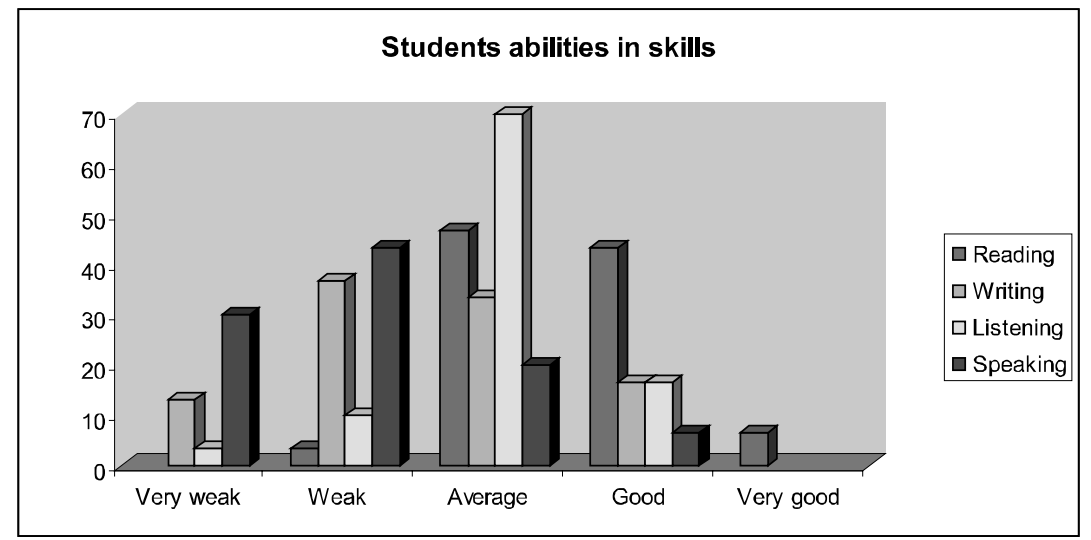

Teachers' perceived:

- $>45 \%$ students as "average" \& $50 \%$ are "good" or above in Reading

- In Writing opinions were divided between 50\% "very weak weak" students \& 50\% "average - good" students

- In Listening - majority (70\%) "average", a few (>15\%) "good"

- In Speaking - majority (>70\%) "weak - very weak". some $(20 \%)$ "average"

Conspicuously teachers did not perceive students as "very good" at any other skill except reading.
Teachers' perception of the importance of English for academic success

The teachers' opinion regarding whether English was a deciding factor for the students' academic success is presented in Figure 5.

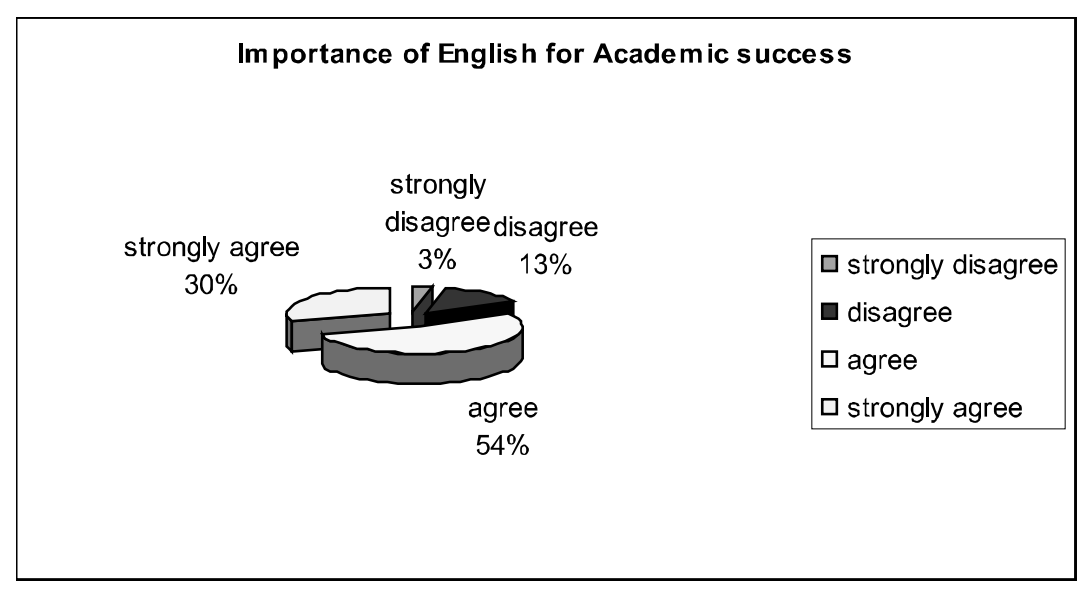

Figure 5: Teachers' perception of the importance of English for academic success

Significantly the teachers unanimously perceived - proficiency in all four skills as "important" for students' academic success.

Freshmen Humanities Students' perceptions of Reading Ability Table 1 displays the findings for the students' perceived ability in the reading sub-skills:

Table 1: Ability in reading sub-skills

\begin{tabular}{|c|c|c|}
\hline V weak- & Average & Good-V \\
\hline Weak & $\mathrm{N} \%$ & good \\
\hline $\mathrm{N} \quad \%$ & & $\mathrm{~N}$ \\
\hline $7(11.7)$ & $31(51.7)$ & $22(3$ \\
\hline
\end{tabular}

$\begin{array}{llll}\text { Reading a text quickly to get a } & 7(11.7) & 31(51.7) & 22(36.7)\end{array}$ general idea of its content

Looking through a text $12(20) \quad 26(43.3) \quad 22(36.7)$ quickly to find specific information

Guessing the meanings of

12(20) $\quad 38(63.3) \quad 10(16.7)$
unknown words from their context 


$\begin{array}{lccc}\begin{array}{l}\text { Understanding the main points } \\ \text { of a text }\end{array} & 10(16.7) & 23(38.3) & 27(45) \\ \begin{array}{l}\text { Reading a text slowly \& } \\ \text { carefully to understand the }\end{array} & 5(8.3) & 20(33.3) & 35(58.3) \\ \text { details of the text } & & & \\ \begin{array}{l}\text { Reading to respond critically } \\ \text { Understanding a writer's }\end{array} & 17(28.3) & 32(53.3) & 11(18.3) \\ \text { attitude \& purpose } & 29(48.3) & 5(8.3) \\ \begin{array}{l}\text { Understand \& interpret charts, } \\ \text { graphs, tables }\end{array} & 14(23.3) & 25(41.7) & 21(35) \\ \begin{array}{l}\text { General comprehension } \\ \text { *All figures within parentheses are in percentages }\end{array} & 31(51.7) & 21(35)\end{array}$

The majority (56.6-91.7\%) claims to be "average" and above but many are "weak" at:

- looking through a text quickly to find specific information (20\%)

- guessing the meanings of unknown words from their context $(20 \%)$

- reading to respond critically $(43.3 \%)$

- understanding a writer's attitude and purpose $(28.4 \%)$

- understanding and interpreting charts, graphs, tables (23.4\%)

The findings support the Teachers' perception that students are "average" in reading.

Freshmen Humanities Students' perceptions of Writing Ability

Table 2 illustrates the findings for the students' ability in the writing sub-skills.

\section{Table 2: Ability in writing sub-skills}

$\begin{array}{lccc} & \begin{array}{c}\text { Weak-very } \\ \text { weak }\end{array} & \begin{array}{c}\text { Average... } \\ \text { N } \%\end{array} & \begin{array}{c}\text { Good-very } \\ \text { good. }\end{array} \\ \text { Using correct } & \mathrm{N} \% & & \mathrm{~N} \% \\ \text { punctuation \& spelling } & 7(11.6) & 38 & 15(25) \\ \text { Structuring sentences } & 13(21.7) & (63.3 \%) & \\ & & (53.3 \%) & 15(25) \\ \text { Using appropriate } & 19(31.7) & 29 & 12(20) \\ \text { vocabulary } & & (48.3 \%) & \end{array}$

\begin{tabular}{|c|c|c|c|}
\hline Organizing paragraphs & $20(33.3)$ & $\begin{array}{c}26 \\
(43.3 \%)\end{array}$ & $14(23.3)$ \\
\hline $\begin{array}{l}\text { Organizing the overall } \\
\text { assignment }\end{array}$ & $19(31.7)$ & $33(55 \%)$ & $8(13.3)$ \\
\hline $\begin{array}{l}\text { Expressing ideas } \\
\text { appropriately }\end{array}$ & $18(30)$ & $24(40 \%)$ & $18(30)$ \\
\hline Developing ideas & $17(28.3)$ & $\begin{array}{c}25 \\
(41.7 \%)\end{array}$ & $18(30)$ \\
\hline $\begin{array}{l}\text { Expressing what you } \\
\text { want to say clearly }\end{array}$ & $12(20)$ & $\begin{array}{c}28 \\
(46.7 \%)\end{array}$ & $20(33.3)$ \\
\hline Addressing the topic & $16(26.7)$ & $27(45 \%)$ & $17(28.3)$ \\
\hline $\begin{array}{l}\text { Adopting appropriate } \\
\text { tone \& style }\end{array}$ & $25(41.7)$ & $24(40 \%)$ & $11(18.3)$ \\
\hline $\begin{array}{l}\text { Following instructions } \\
\& \text { directions }\end{array}$ & $19(31.7)$ & $\begin{array}{c}23 \\
(38.3 \%)\end{array}$ & $18(30)$ \\
\hline $\begin{array}{l}\text { Evaluating \& revising } \\
\text { your writing }\end{array}$ & $13(21.7)$ & $27(45 \%)$ & $20(33.3)$ \\
\hline Overall writing ability & $11(18.3)$ & $27(45 \%)$ & $22(36.7)$ \\
\hline $\begin{array}{l}\text { Completing written } \\
\text { tasks }\end{array}$ & $16(26.7)$ & $25(41.7 \%)$ & $19(31.7)$ \\
\hline
\end{tabular}

The majority (58.4-88.3\%) claims to be "average" and above but many are "weak" at:

- $\quad$ using appropriate vocabulary $(31.7 \%)$

- $\quad$ organizing paragraphs $(33.3 \%)$

- $\quad$ organizing the overall assignment $(31.7 \%)$

- $\quad$ expressing ideas appropriately $(30.4 \%)$

- $\quad$ adopting appropriate tone and style (41.6\%)

- $\quad$ following instructions \& directions (31.6\%)

Thus many students are "weak" at the writing sub-skills. The teachers' findings support the finding that the majority of the students (57\%) are "weak" at writing. 


\section{Freshmen Humanities Students' perceptions of Listening Ability}

Table 3 presents the results of students' ability in the listening subskills:

\section{Table 3: Ability in listening sub-skills}

$\begin{array}{lccc} & \begin{array}{c}\text { Weak-V } \\ \text { weak }\end{array} & \begin{array}{c}\text { Average } \\ \mathrm{N} \%\end{array} & \begin{array}{c}\text { Good- V } \\ \text { good }\end{array} \\ \begin{array}{l}\text { Listen to \& understand lectures } \\ \text { \& notes }\end{array} & 5(8.3) & 36(60) & \begin{array}{c}\text { N } \%(31.7) \\ \text { Listen to \& carry out }\end{array} \\ \begin{array}{l}\text { instructions/directions } \\ \text { Listen to \& understand } \\ \text { class/tutorial discussions }\end{array} & 15(25) & 29(48.3) & 16(26.7) \\ \begin{array}{l}\text { Listen to \& understand } \\ \text { questions/points raised during } \\ \text { class /tutorials }\end{array} & 7(11.7) & 29(48.3) & 24(40) \\ \begin{array}{l}\text { Listen to \& answer questions in } \\ \text { class/tutorials }\end{array} & 10(16.7) & 30(50) & 20(33.3) \\ \begin{array}{l}\text { Listen to \& understand seminars } \\ \text { \& talks }\end{array} & 16(26.7) & 32(53.3) & 12(20) \\ \begin{array}{l}\text { Listen to \& understand } \\ \text { television programs }\end{array} & 9(15) & 33(55) & 18(30) \\ \begin{array}{l}\text { Listen to \& understand radio } \\ \text { programs }\end{array} & 12(20) & 26(43.3) & 22(36.7) \\ \begin{array}{l}\text { Listen to \& understand different } \\ \text { English accents }\end{array} & 17(28.3) & 33(55) & 10(16.7)\end{array}$

*All figures within parentheses are in percentages

The majority (71.6-91.7\%), claims to be "average" and above; many are "weak" at listening to and:

- $\quad$ carrying out instructions or directions $(25 \%)$

- $\quad$ understanding seminars and talks $(26.6 \%)$

- $\quad$ understanding radio programs $(20 \%)$

- $\quad$ understanding different English accents (28.4\%)
This indicates that many are "weak" at listening sub-skills. The teachers' findings are contradictory as most teachers (86\%) perceived the students as average and above in listening.

Freshmen Humanities Students' perceptions of Speaking Ability Table 4 depicts the findings for the students' ability in the speaking sub-skills.

\section{Table 4: Ability in speaking sub-skills}

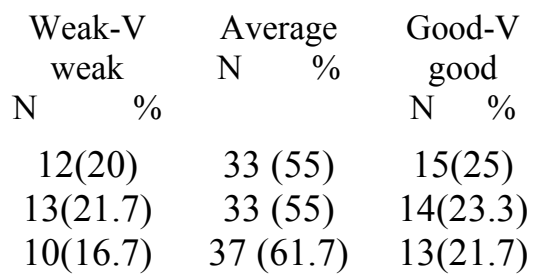$$
\begin{array}{lccc}
\text { Asking questions } & 13(21.7) & 33(55) & 14(23.3) \\
\text { Answering questions } & 10(16.7) & 37(61.7) & 13(21.7) \\
\text { Expressing opinions } & & &
\end{array}
$$$$
\begin{aligned}
& \text { /objections } \\
& \text { Delivering oral presentations } \quad 21(35) \quad 30(50) \quad 9(15)
\end{aligned}
$$$$
\text { /reports }
$$$$
\begin{array}{llll}
\text { Explaining processes } & \text { 26(43.3) } & 26(43.3) & 8(13.3)
\end{array}
$$$$
\text { /procedures }
$$$$
\begin{array}{llll}
\text { Brainstorming } & \text { 22(36.7) } & 31(51.7) & 7(11.7)
\end{array}
$$$$
\begin{array}{llll}
\text { Taking part in class/tutorial } & 15(25) & 28(46.7) & 17(28.3)
\end{array}
$$$$
\text { /group discussions }
$$$$
\begin{array}{lll}
\text { Taking part in social } & 17(28.3) & 24(40)
\end{array}
$$$$
\text { conversations }
$$$$
\begin{array}{llll}
\text { Speaking with other fluent } \quad 23(38.3) & 25(41.7) & 12(20)
\end{array}
$$$$
\text { speakers of English }
$$

*All figures within parentheses are in percentages

The majority (56.7-83.3\%) rated themselves as "average" but many are "weak" at:

- delivering oral presentations or reports $(35 \%)$

- $\quad$ explaining processes or procedures $(43.3 \%)$

- $\quad$ brainstorming (36.7\%)

- taking part in class or tutorial or group discussions (25\%)

- $\quad$ taking part in social conversations (28.3\%)

- $\quad$ speaking with other fluent speakers of English (38.3\%) 
It may be surmised that many students are weak at the speaking subskills this corresponds to the finding that most teachers $(57 \%)$ perceived students as "weak" at speaking sub-skills.

\section{Overview of Course Usefulness and Learning}

Teachers' perception of the usefulness of the present English courses in teaching students the sub-skills

The teachers' perception of the usefulness of the existing English courses in teaching students the various language sub-skills was examined. Table 5 presents the findings for the course's helpfulness in teaching the reading sub-skills.

Table 5: Teachers' perception of the usefulness of the present course in teaching students reading sub-skills

\begin{tabular}{|c|c|c|c|c|c|}
\hline & $\begin{array}{l}\text { Not at all } \\
\text { helpful }\end{array}$ & $\begin{array}{l}\text { Not very } \\
\text { helpful }\end{array}$ & $\begin{array}{c}\text { A bit } \\
\text { helpful }\end{array}$ & $\begin{array}{l}\text { Quite } \\
\text { helpful }\end{array}$ & $\begin{array}{c}\text { Very } \\
\text { helpful }\end{array}$ \\
\hline & $\mathrm{N} \quad \%$ & $\mathrm{~N} \quad \%$ & $\mathrm{~N} \quad \%$ & & \\
\hline $\begin{array}{l}\text { Reading a text quickly } \\
\text { to get a general idea of } \\
\text { its content }\end{array}$ & - & $3(10)$ & $\begin{array}{c}10 \\
(33.3)\end{array}$ & $12(40)$ & $\begin{array}{c}5 \\
(16.7)\end{array}$ \\
\hline $\begin{array}{l}\text { Looking through a text } \\
\text { quickly to find specific } \\
\text { information }\end{array}$ & - & $3(10)$ & $12(40)$ & $12(40)$ & $3(10)$ \\
\hline $\begin{array}{l}\text { Guessing the meanings } \\
\text { of unknown words from } \\
\text { their context }\end{array}$ & $1(3.3)$ & $4(13.3)$ & $\begin{array}{c}11 \\
(36.7)\end{array}$ & $\begin{array}{c}11 \\
(36.7)\end{array}$ & $3(10)$ \\
\hline $\begin{array}{l}\text { Understanding the main } \\
\text { points of a text }\end{array}$ & $1(3.3)$ & $2(6.7)$ & $\begin{array}{c}10 \\
(33.3)\end{array}$ & $\begin{array}{c}10 \\
(33.3)\end{array}$ & $\begin{array}{c}7 \\
(23.3)\end{array}$ \\
\hline $\begin{array}{l}\text { Reading a text slowly \& } \\
\text { carefully to understand } \\
\text { the details of the text }\end{array}$ & - & $4(13.3)$ & $\begin{array}{c}10 \\
(33.3)\end{array}$ & $\begin{array}{c}10 \\
(33.3)\end{array}$ & $6(20)$ \\
\hline $\begin{array}{l}\text { Reading to respond } \\
\text { critically }\end{array}$ & $2(6.7)$ & $5(16.7)$ & $7(23.3)$ & $\begin{array}{c}13(43.3 \\
)\end{array}$ & $3(10)$ \\
\hline $\begin{array}{l}\text { Understanding a } \\
\text { writer's attitude \& } \\
\text { purpose }\end{array}$ & $3(10)$ & $5(16.7)$ & $\begin{array}{c}13 \\
(43.3)\end{array}$ & $5(16.7)$ & $\begin{array}{c}4 \\
(13.3)\end{array}$ \\
\hline $\begin{array}{l}\text { Understand \& interpret } \\
\text { charts, graphs, tables }\end{array}$ & $\begin{array}{c}5 \\
(16.7)\end{array}$ & $6(20)$ & $5(16.7)$ & $12(40)$ & $2(6.7)$ \\
\hline General comprehension & $1(3.3)$ & $2(6.7)$ & $10(33.3)$ & $\begin{array}{c}11 \\
(36.7)\end{array}$ & $6(20)$ \\
\hline
\end{tabular}

*All figures within parentheses are in percentages

Most teachers (70-90\%) felt the course was useful in teaching the reading sub-skills. But many teachers (10-36.7\%) felt the course was not helpful in teaching:
- understanding and interpreting charts or graphs or tables $(36.7 \%)$

- understanding a writer's attitude and purpose (26.7\%)

- reading to respond critically $(23.5 \%)$

- guessing the meanings of unknown words from their context $(16.6 \%)$

The findings reflect Basturkmen \& Al Huneidi's (1996) and Akin \& Guceri's (2001) findings that faculty members were not satisfied with prescribed reading courses.

Teachers' perception of the usefulness of the present course in teaching students writing sub-skills

The results of the course's helpfulness in teaching the writing subskills are displayed in Table 6:

Table 6: Teachers' perception of the usefulness of the present course in teaching students Writing sub-skills

\begin{tabular}{|c|c|c|c|c|c|}
\hline & $\begin{array}{l}\text { Not at all } \\
\text { helpful }\end{array}$ & $\begin{array}{l}\text { Not very } \\
\text { helpful }\end{array}$ & $\begin{array}{l}\text { A bit } \\
\text { helpful }\end{array}$ & $\begin{array}{l}\text { Quite } \\
\text { helpful }\end{array}$ & $\begin{array}{l}\text { Very } \\
\text { helpful }\end{array}$ \\
\hline & $\mathrm{N} \quad \%$ & $\mathrm{~N} \quad \%$ & $\mathrm{~N} \quad \%$ & & \\
\hline $\begin{array}{l}\text { Using correct } \\
\text { punctuation \& } \\
\text { spelling }\end{array}$ & $1(3.3)$ & $3(10)$ & $\begin{array}{c}11 \\
(36.7)\end{array}$ & $9(30)$ & $6(20)$ \\
\hline $\begin{array}{l}\text { Structuring } \\
\text { sentences }\end{array}$ & $1(3.3)$ & $3(10)$ & $7(23.3)$ & $12(40)$ & $7(23.3)$ \\
\hline $\begin{array}{l}\text { Using } \\
\text { appropriate } \\
\text { vocabulary }\end{array}$ & - & $4(13.3)$ & $9(30)$ & $14(46.7)$ & $3(10)$ \\
\hline $\begin{array}{l}\text { Organizing } \\
\text { paragraphs }\end{array}$ & & $6(20)$ & $7(23.3)$ & $10(33.3)$ & $7(23.3)$ \\
\hline $\begin{array}{l}\text { Organizing the } \\
\text { overall } \\
\text { assignment }\end{array}$ & $2(6.7)$ & $1(3.3)$ & $\begin{array}{c}10 \\
(33.3)\end{array}$ & $10(33.3)$ & $7(23.3)$ \\
\hline $\begin{array}{l}\text { Expressing } \\
\text { ideas } \\
\text { appropriately }\end{array}$ & - & $5(16.7)$ & $9(30)$ & $9(30)$ & $7(23.3)$ \\
\hline $\begin{array}{l}\text { Developing } \\
\text { ideas }\end{array}$ & - & $4(13.3)$ & $\begin{array}{c}11 \\
(36.7)\end{array}$ & $10(33.3)$ & $5(16.7)$ \\
\hline $\begin{array}{l}\text { Expressing } \\
\text { what you want } \\
\text { to say clearly }\end{array}$ & $1(3.3)$ & $3(10)$ & $\begin{array}{c}10 \\
(33.3)\end{array}$ & $12(40)$ & $4(13.3)$ \\
\hline $\begin{array}{l}\text { Addressing the } \\
\text { topic }\end{array}$ & $1(3.3)$ & $4(13.3)$ & $8(26.7)$ & $14(46.7)$ & $3(10)$ \\
\hline
\end{tabular}




$\begin{array}{lccccc}\begin{array}{l}\text { Adopting } \\ \text { appropriate } \\ \text { tone \& style }\end{array} & 2(6.7) & 6(20) & \begin{array}{c}13 \\ (43.3)\end{array} & 9(30) & \\ \begin{array}{l}\text { Following } \\ \text { instructions \& } \\ \text { directions }\end{array} & 1(3.3) & 2(6.7) & 12(40) & 12(40) & 3(10) \\ \begin{array}{l}\text { Evaluating \& } \\ \text { revising your }\end{array} & 1(3.3) & 2(6.7) & 9(30) & 12(40) & 6(20) \\ \begin{array}{l}\text { writing } \\ \begin{array}{l}\text { Overall } \\ \text { writing ability }\end{array}\end{array} & 5(16.7) & 7(23.3) & 11(36.7) & 7(23.3) \\ \begin{array}{l}\text { Completing } \\ \text { written tasks }\end{array} & 5(16.7) & 13 & 8(26.7) & 4(13.3) \\ * \text { All figures within parentheses a in percintages } & & \end{array}$

*All figures within parentheses are in percentages

Most teachers (73.3-90\%) felt the course helped in teaching the writing sub-skills. Some teachers felt the course did not help in teaching:

- adopting appropriate tone and style (26.7\%)

- organizing paragraphs $(20 \%)$

- expressing ideas appropriately $(16.7 \%)$

- $\quad$ addressing the topic (16.7\%)

- overall writing ability $(16.7 \%)$

- completing written tasks (16.7\%)

- using correct punctuation and spelling (13.3\%)

- $\quad$ structuring sentences $(13.3 \%)$

- using appropriate vocabulary $(13.3 \%)$

- developing ideas(13.3\%)

- expressing what you want to say clearly (13.3\%)

The findings correspond to Basturkmen \& Al Huneidi's (1996) and Zhu \& Flaitz's (2005) findings that faculty members were not satisfied with prescribed writing courses.

Teachers' perception of the usefulness of the present course in teaching students listening sub-skills

The results of the course's helpfulness in teaching the listening subskills are given in Table 7.
Table 7: Teachers' perception of the usefulness of the present course in teaching students listening sub-skills

$\begin{array}{ccccc}\text { Not at all } & \text { Not very } & \text { A bit } & \text { Quite } & \text { Very } \\ \text { helpful } & \text { helpful } & \text { helpful } & \text { helpful } & \text { helpful } \\ \mathrm{N} \% & \mathrm{~N} \% & \mathrm{~N} \% & \mathrm{~N} \% & \mathrm{~N} \% \\ 1(3.3) & 5 & 9(30) & 10 & 5 \\ & (16.7) & & (33.3) & (16.7) \\ & 5 & 7 & 13 & 5 \\ & (16.7) & (23.3) & (43.3) & (16.7) \\ - & 4 & 8 & 12(40) & 6(20) \\ & (13.3) & (26.7) & & \\ - & 2(6.7) & 11 & 13 & 4 \\ & & (36.7) & (43.3) & (13.3) \\ - & 4 & 7 & 14 & 5 \\ & (13.3) & (23.3) & (46.70 & (16.7) \\ 1(3.3) & 6(20) & 9(30) & 9(30) & 5 \\ 3(10) & 3(10) & 11 & 9(30) & 4 \\ 4 & 4 & 11 & 9(30) & 2(6.7) \\ (13.3) & (13.3) & (36.7) & & \\ 5 & 5 & 6(20) & 11 & 3(10) \\ (16.7) & (16.7) & & (36.7) & \end{array}$

Listen to \& understand

lectures \& notes

Listen to \& carry out instructions/directions

Listen to \& understand class/tutorial discussions Listen to \& understand questions/points raised during class /tutorials

Listen to \& answer questions

class/tutorials

seminars \& talks

Listen to \& understan

television programs

Listen to \& understan

radio programs

Listen to \& understand

different English accents

(16.7)

in percentages

Many teachers $(>65 \%)$ felt the course helped teach the listening subskills. But a lot of teachers (6.7-33.4\%) felt the course did not help teach: listening to and understanding:

- lectures and notes $(20 \%)$

- seminars and talks (23.3\%)

- class and tutorial discussions (13.3\%)

- listening to and carrying out instructions and directions $(16.7 \%)$

- listening to and answering questions in class and tutorials $(13.3 \%)$ 
Dooey's (2006) findings supported these findings.

Teachers' perception of the usefulness of the English course in teaching Students' speaking sub-skills

Table 8 illustrates the results of the course's helpfulness in teaching speaking sub-skills.

Table 8: Teachers' perception of the usefulness of the present course in teaching Students' speaking sub-skills

\begin{tabular}{|c|c|c|c|c|c|}
\hline & $\begin{array}{l}\text { Not at } \\
\text { all }\end{array}$ & $\begin{array}{l}\text { Not very } \\
\text { helpful }\end{array}$ & $\begin{array}{l}\text { A bit } \\
\text { helpful }\end{array}$ & $\begin{array}{l}\text { Quite } \\
\text { helpful }\end{array}$ & $\begin{array}{l}\text { Very } \\
\text { helpful }\end{array}$ \\
\hline & & & & & \\
\hline & $\mathrm{N} \quad \%$ & & & & \\
\hline sking questions & - & $6(20)$ & $8(26.7)$ & $12(40)$ & $4(13.3)$ \\
\hline $\begin{array}{l}\text { nswer } \\
\text { lestio }\end{array}$ & - & $5(16.7)$ & & $\begin{array}{c}10 \\
(33.3)\end{array}$ & $6(20)$ \\
\hline $\begin{array}{l}\text { xpressing opinions } \\
\text { bjections }\end{array}$ & $3(10)$ & $6(20)$ & $7(23.3)$ & $8(26.7)$ & $6(20)$ \\
\hline $\begin{array}{l}\text { Delivering oral } \\
\text { presentations } \\
\text { /reports }\end{array}$ & $2(6.7)$ & $4(13.3)$ & $7(23.3)$ & $\begin{array}{c}13 \\
(43.3)\end{array}$ & $4(13.3)$ \\
\hline $\begin{array}{l}\text { Explaining } \\
\text { processes } \\
\text { /procedures }\end{array}$ & $3(10)$ & $5(16.7)$ & $8(26.7)$ & $9(30)$ & $5(16.7)$ \\
\hline Brainstorming & $3(10)$ & $2(6.7)$ & $\begin{array}{c}13 \\
(43.3)\end{array}$ & $9(30)$ & $3(10)$ \\
\hline $\begin{array}{l}\text { Taking part in } \\
\text { class/tutorial /group } \\
\text { discussions }\end{array}$ & $1(3.3)$ & $3(10)$ & $\begin{array}{c}11 \\
(36.7)\end{array}$ & $12(40)$ & $3(10)$ \\
\hline $\begin{array}{l}\text { Taking part in } \\
\text { social conversations }\end{array}$ & $3(10)$ & $5(16.6)$ & $7(23.3)$ & $\begin{array}{c}14 \\
(46.7)\end{array}$ & $1(3.3)$ \\
\hline $\begin{array}{l}\text { Speaking with other } \\
\text { fluent speakers of } \\
\text { English }\end{array}$ & $7(23.3)$ & $4(13.3)$ & $7(23.3)$ & $9(30)$ & $3(10)$ \\
\hline & & & & & \\
\hline b & & & & & \\
\hline
\end{tabular}

- expressing opinions or objections $(30 \%)$

- explaining processes or procedures (26.7\%)

- asking questions (20\%)

- delivering oral presentations or reports $(20 \%)$
The findings are congruent with Dooey's (2006) findings. Students' perception of the learning \& usefulness of course

The results for the learning and usefulness of the course are illustrated in Table 9.

\section{Table 9: Learning \& usefulness of course}

Never Sometimes Often

$\begin{array}{llll}\text { I learned a lot about English language usage } & 1.7 & 40 & 58.3\end{array}$

from using the course materials

$\begin{array}{lll}\text { My English has improved as a result of the } & 26.7 & 73.3\end{array}$

activities done in class

The course will be useful for my studies $\quad 15 \quad 85$

The course will be useful for my future $\quad 10 \quad 90$

career

I feel more confident about using English in

my studies

I feel confident about using English for my

career purposes

Note: Data is presented in percentages (\%)

It is observed that the majority of the students strongly agreed about the above mentioned learning and usefulness aspects of the courses.

\section{Teachers' perception of the learning \& usefulness of course}

Table 10 presents the results for the teachers' opinions about the learning and usefulness of the course.

Table 10: Teachers' perception of the learning \& usefulness of course

\begin{tabular}{|c|c|c|c|c|c|}
\hline 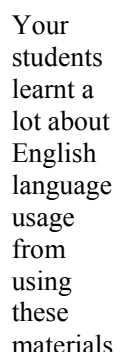 & $\begin{array}{l}\text { Your } \\
\text { students' } \\
\text { English } \\
\text { has } \\
\text { improved } \\
\text { as a result } \\
\text { of the } \\
\text { activities } \\
\text { done in } \\
\text { class }\end{array}$ & $\begin{array}{l}\text { The } \\
\text { course } \\
\text { will be } \\
\text { useful for } \\
\text { your } \\
\text { students' } \\
\text { studies }\end{array}$ & $\begin{array}{l}\text { The } \\
\text { course } \\
\text { will be } \\
\text { useful for } \\
\text { your } \\
\text { students' } \\
\text { future } \\
\text { career } \\
\text { needs }\end{array}$ & $\begin{array}{l}\text { Your } \\
\text { students } \\
\text { feel more } \\
\text { confident } \\
\text { about } \\
\text { using } \\
\text { English in } \\
\text { their } \\
\text { studies }\end{array}$ & $\begin{array}{l}\text { Your } \\
\text { students } \\
\text { feel } \\
\text { confiden } \\
\text { t about } \\
\text { using } \\
\text { English } \\
\text { for their } \\
\text { career } \\
\text { purposes }\end{array}$ \\
\hline $3(10)$ & - & $1(3.3)$ & $1(3.3)$ & $2(6.7)$ & $1(3.3)$ \\
\hline
\end{tabular}

disagree 


$\begin{array}{lcccccc}\text { Disagree } & 6(20) & 6(20) & 4(13.3) & 5(16.7) & 7(23.3) & 6(20) \\ \text { Not sure } & 16(53.3) & 15(50) & 7(23.3) & 6(20) & 12(40) & 11 \\ & & & & & & (36.7) \\ \text { Agree } & 5(16.7) & 7(23.3) & 17(56.7) & 15(50) & 8(26.7) & 11 \\ & & & & & & (36.7) \\ \text { Strongly } & - & 2(6.7) & 1(3.3) & 3(10) & 1(3.3) & 1(3.3)\end{array}$

agree

*All figures within parentheses are in percentages

Remarkable numbers of teachers unsure \& disagreed whether students

- learnt language usage

- English improved

- felt confident about using English in their studies

- felt confident about using English for career purposes

- course was useful for students' studies \& future career needs Course effectiveness in terms of students' pre-course and postcourse skills use frequencies

The effectiveness of the course in terms of whether there was any noticeable change in the students' use of the skills before and after doing the course was explored in order to ascertain course usefulness. Table 11 presents the findings for the students' frequencies of skills use before and after doing the course.

Table 11: Distribution of skills use frequencies before and after the course

\begin{tabular}{llllllllll} 
& \multicolumn{2}{l}{ Reading } & \multicolumn{2}{c}{ Writing } & \multicolumn{2}{c}{ Listening } & \multicolumn{2}{c}{ Speaking } \\
& Pre & Post & Pre & Post & Pre & Post & Pre & Post \\
& C & C & C & C & C & C & C & C \\
Never & 5.0 & 1.7 & 10.0 & 1.7 & 5.0 & 0 & 6.7 & 3.3 \\
Sometimes & 36.7 & 15.0 & 45.0 & 28.3 & 36.7 & 26.7 & 41.7 & 30.0 \\
Often & 25.0 & 36.7 & 23.3 & 43.3 & 33.3 & 30.0 & 30.0 & 31.7 \\
very often & 16.7 & 26.7 & 13.3 & 18.3 & 18.3 & 28.3 & 18.3 & 21.7 \\
Always & 16.7 & 20.0 & 8.3 & 8.3 & 6.7 & 15.0 & 3.3 & 13.3
\end{tabular}

Note: Data is presented in percentages (\%)

The Dhaka University Journal of Linguistics
Outstandingly there is:

- a marked increase in students who "often-very often-always" read

- a rise in students who "often-very often" write

- an increase in the number of students who "very oftenalways" listen

- an increase in the number who "often-very often-always" speak

Thus indicating the courses are helpful to some extent.

\section{Overview of Course Difficulty}

Table 12 presents the findings for the difficulty the students faced in following the course in class.

Table 12: Difficulty faced by students in following the course in class

$\begin{array}{llll} & \text { Never } & \text { Sometimes } & \text { Often } \\ \begin{array}{l}\text { The discussions in class were } \\ \text { difficult for me }\end{array} & 8.3 & 56.7 & 35 \\ \begin{array}{l}\text { The language of the course } \\ \text { book/handout /materials were }\end{array} & 6.7 & 53.3 & 40 \\ \begin{array}{l}\text { difficult for me } \\ \begin{array}{l}\text { The tasks and activities were } \\ \text { difficult for me to do }\end{array}\end{array} & 6.7 & 53.3 & 40 \\ \begin{array}{l}\text { I had difficulty in completing the } \\ \text { given work on time in class }\end{array} & 8.3 & 65 & 35\end{array}$

Note: Data is presented in percentages (\%)

It is noteworthy that the majority (53.3-65\%) of the students "sometimes" and "often" (35-40\%) faced difficulty with all of the above. It maybe inferred that the course; materials and tasks are difficult.

Teachers' perceptions of course difficulty

The results for the difficulty level of the course from the teachers' perspective are given in Table 13.

Vol. 2 No. 4, August 2009 
Table 13: Teachers' perceptions of course difficulty

$\begin{array}{lcclc} & \begin{array}{l}\text { The } \\ \text { discussions } \\ \text { in class were } \\ \text { difficult for } \\ \text { your students } \\ \text { to follow }\end{array} & \begin{array}{l}\text { The language of } \\ \text { the course } \\ \text { book/handout } \\ \text { /materials were } \\ \text { difficult for your } \\ \text { students to } \\ \text { follow }\end{array} & \begin{array}{l}\text { The tasks } \\ \text { and } \\ \text { activities } \\ \text { were } \\ \text { difficult } \\ \text { for your } \\ \text { students to } \\ \text { do }\end{array} & \begin{array}{l}\text { Your students } \\ \text { had difficulty } \\ \text { in completing } \\ \text { the given } \\ \text { work on time } \\ \text { in class }\end{array} \\ \begin{array}{l}\text { Strongly } \\ \text { disagree }\end{array} & 3(10) & 1(3.3) & 2(6.7) & 4(13.3) \\ \text { Disagree } & 9(30) & 11(36.7) & 15(50) & 8(26.7) \\ \text { Not sure } & 9(30) & 8(26.7) & 8(26.7) & 11(36.7) \\ \text { Agree } & 9(30) & 9(30) & 5(16.7) & 4(13.3) \\ \text { Strongly } & - & 1(3.3) & - & 3(10)\end{array}$

*All figures within parentheses are in percentages

Most teachers (40-56.7\%) felt the course was not difficult but many teachers (16.7-33.3\%) disagreed and a considerable number (26.7$36.7 \%$ ) were "unsure"; so it can be assumed that the course is quite difficult.

\section{Overview Of Classroom Teaching Styles}

Overview of the students' perceptions of prevalent teaching styles and preferred teaching styles

Table 14 illustrates the students' perceptions of the most frequently used teaching styles.

Table 14: Frequency of the different classroom teaching styles being used

$\begin{array}{lccc} & \text { Never } & \text { Sometimes } & \text { Often } \\ & \mathrm{N} \% & \mathrm{~N} \% & \mathrm{~N} \% \\ \text { Lecturing } & 1(1.7) & 23(38.3) & 36(60) \\ \text { Teacher asking questions \& students } & 3(5) & 30(50) & 27(45) \\ \text { answering } & & & \\ \begin{array}{l}\text { Group discussions with teacher as } \\ \text { facilitator }\end{array} & 4(6.7) & 28(46.7) & 28(46.7) \\ \begin{array}{l}\text { Students given work \& working } \\ \text { Str.3) }\end{array} & 32(53.3) & 23(38.3)\end{array}$

independently out of class

The Dhaka University Journal of Linguistics

\begin{tabular}{|c|c|c|c|}
\hline Student presentations & $8(13.3)$ & $38(63.3)$ & $14(23.3)$ \\
\hline & $9(15)$ & $36(60)$ & $15(25)$ \\
\hline $\begin{array}{l}\text { in class } \\
\text { Using drama music role plays } \\
\text { games }\end{array}$ & $5(8.3)$ & $37(61.7)$ & $18(30)$ \\
\hline Group or pair work & $13(21.7)$ & $29(48.3)$ & $18(30)$ \\
\hline
\end{tabular}

*All figures within parentheses are in percentages

Lecturing (60\%); group discussions with teacher as facilitator (46.7\%); and teacher asking questions and students answering (45\%) are the most frequently used teaching styles.

Table 15 illustrates the students' perceptions of teaching styles they prefer.

Table 15: Students' preferences of teaching styles

\begin{tabular}{|c|c|c|}
\hline $\begin{array}{c}\text { Not very } \\
\text { helpful }\end{array}$ & $\begin{array}{c}\text { A bit } \\
\text { helpful.. }\end{array}$ & $\begin{array}{l}\text { Quite } \\
\text { helpful }\end{array}$ \\
\hline $\mathrm{N} \quad \%$ & $\mathrm{~N} \%$ & $\mathrm{~N} \%$ \\
\hline $4(6.7)$ & $11(18.3)$ & $45(75)$ \\
\hline $2(3.3)$ & $5(8.3)$ & $53(88.3)$ \\
\hline $2(3.3)$ & $7(11.7)$ & $51(85)$ \\
\hline $4(6.7)$ & $14(23.3)$ & $42(70)$ \\
\hline $2(3.3)$ & $11(18.3)$ & $47(78.3)$ \\
\hline $\begin{array}{l}17 \\
(28.3)\end{array}$ & 13 (21.7) & $30(50)$ \\
\hline $8(13.3)$ & 13 (21.7) & $39(65)$ \\
\hline $5(8.3)$ & $11(18.3)$ & $44(73.3)$ \\
\hline $5(8.3)$ & $9(15)$ & $46(76.7)$ \\
\hline
\end{tabular}

Lecturing

Teacher asking questions \&

students answering

Group discussions with

teacher as facilitator

Students given work \&

working independently out

of class

Student presentations

Students silently doing

written work in class

Using drama music role

plays games

Group or pair work

$5(8.3)$

$9(15)$

$46(76.7)$

fieldwork

*All figures within parentheses are in percentages 
In the students' perception the most helpful teaching styles are, teacher asking questions and students answering (88.3\%); group discussions with teacher as facilitator (85\%); and student presentations (78.3\%); followed by, students doing practical fieldwork (76.7\%), lecturing (75\%); and group or pair work $(73.3 \%)$; and students given work and working independently out of class $(70 \%)$.

\section{Overview of teachers' perceptions of prevalent classroom teaching styles}

Table 16 displays the findings for the teachers' perceptions of the most frequently used teaching styles.

\begin{tabular}{|c|c|c|c|c|c|}
\hline & Never & Rarely & $\begin{array}{l}\text { Sometim } \\
\text { es }\end{array}$ & Often & $\begin{array}{l}\text { Very } \\
\text { often }\end{array}$ \\
\hline Lecturing & - & $3(10)$ & $5(16.7)$ & $5(16.7)$ & $\begin{array}{l}17 \\
(56.7)\end{array}$ \\
\hline $\begin{array}{l}\text { Teacher asking questions } \\
\& \text { students answering }\end{array}$ & - & $2(6.7)$ & $4(13.3)$ & $11(36.7)$ & $\begin{array}{l}13 \\
(43.3)\end{array}$ \\
\hline $\begin{array}{l}\text { Group discussions with } \\
\text { teacher as facilitator }\end{array}$ & $1(3.3)$ & $6(20)$ & $8(26.7)$ & $5(16.7)$ & $\begin{array}{l}10 \\
(33.3)\end{array}$ \\
\hline $\begin{array}{l}\text { Students given work \& } \\
\text { working independently } \\
\text { out of class }\end{array}$ & $1(3.3)$ & $1(3.3)$ & $9(30)$ & $13(43.3)$ & $6(20)$ \\
\hline Student presentations & $1(3.3)$ & $6(20)$ & $6(20)$ & $11(36.7)$ & $6(20)$ \\
\hline $\begin{array}{l}\text { Students silently doing } \\
\text { written work in class }\end{array}$ & $5(16.7)$ & $8(26.7)$ & $7(23.3)$ & $7(23.3)$ & $3(10)$ \\
\hline $\begin{array}{l}\text { Using drama music role } \\
\text { plays games }\end{array}$ & $9(30)$ & $5(16.7)$ & $9(30)$ & $5(16.7)$ & $2(6.7)$ \\
\hline Group or pair work & - & $9(30)$ & $\begin{array}{l}10 \\
(33.3)\end{array}$ & $5(16.7)$ & $6(20)$ \\
\hline Students doing practical & $4(13.3)$ & $8(26.7)$ & $9(30)$ & $8(26.7)$ & $1(3.3)$ \\
\hline
\end{tabular}

fieldwork

*All figures within parentheses are in percentages

The most frequently used teaching styles are: Lecturing; teacher asking questions and students answering, and students given work and working independently out of class.

There is clear disagreement between the students' preferred teaching styles and those which are prevalent (classroom observations, teachers' and students' findings corroborate the prevalence of these teaching styles).

\section{Concluding Thoughts}

From the preceding discussion and observations, it appears that the current classroom and teaching leaves much to be desired and that there is plenty of scope for improvement in the present courses that are being taught at the Humanities faculty. The feedback from the teachers established that their students' abilities fall short of the proficiency level that is required, to academically succeed at the tertiary level. Moreover areas in which the English courses are not fulfilling the teachers' expectations have been identified. The Humanities students' perceptions of their specific needs were identified, their opinions about the present English courses were ascertained; areas in which improvement is required were discovered. It was found that some changes need to be made in teaching style in order for courses to be more effective and learning friendly. Future ELT courses will be benefited greatly if the above mentioned needs and perceptions of Humanities students and teachers are kept in mind whilst specifying the content and designing the courses.

The needs analysis about the Humanities students' and teachers' needs and perceptions identified:

- the specific English language needs of the students of the Humanities Faculty

- areas of difficulty

- what teachers expect the courses to enable their students to be able to do

- whether the courses offered by the various departments reflect the teachers' expectations and needs

- the strengths and shortcomings of the present language courses

- areas in need of improvement

This study raised awareness as it brought to light and provided information to teachers, curriculum experts, and decision makers about what has happens during the courses. The findings of this study pertaining to students' language learning needs, lacks and wants; problems and difficulties, and preferences of classroom teaching style and teachers' perception about students' language 
skills are real eye openers and they have implications for future curriculum development. It is important to remember that evaluation is an intrinsic part of teaching and learning; evaluation is necessary and it is very useful because it provides specific pointers and guidelines to curriculum developers and practitioners for future development of planning and development of courses and for management and implementation of classroom tasks and activities. This study has implications for future EAP courses and may serve as a springboard for discussion of the major areas highlighted in the study and the information provided in this study is important for the decision makers and all others involved.

\section{Bibliography}

Akin, A.R. \& Guceri, M. April 2001. A macro materials evaluation for better or for worse. The Weekly Column, Article 56. Retrieved 4 Nov 2006. http://www.eltnewsletter.com/back/April2001/art562001.htm

Alam F. 2001. The Dhaka University English Curriculum. Revisioning English in Bangladesh, P1-14. UPL

Banu, R. \& Sussex, R., 2001b. English in Bangladesh after Independence. In B.Moore (Ed.) Who's centric now? The present state of post colonial English (122-147) Melbourne. Oxford University Press

Basturkmen, H. \& Al Huneidi, A. 1996. The language needs analysis project at the college of petroleum engineering Kuwait University. ERIC document. Retrieved 10/11/2008

Brindley, G. 1984. Needs analysis and objective setting in the adult migrant education program. Sydney: N. S. W. Adult Migrant Education Service.

Choudhury S. I. 2001. Rethinking the two Englishes. Revisioning English in Bangladesh, p15-27. UPL

Crystal, D. 2003. English as a global language (2 ${ }^{\text {nd }}$ ed.). London, Longman

Dooey, P. 2006. Identifying the listening and speaking needs of international students. In Experience of learning. Proceedings of the $15^{\text {th }}$ Annual Teaching Learning Forum,1-2 February 2006. Perth: The University of Western Australia. http://lsn.curtin.edu.au/tlf/tlf2006/ refereed/dooey.html

Dudley Evans, T. and St. John, M.J. 1998 Developments in English for specific purposes: A multi-disciplinary approach. Cambridge: Cambridge University Press.

The Dhaka University Journal of Linguistics
Ellis, R. 1998. Teaching and research: Options in grammar teaching. TESOL Quarterly, 32, 139-60.

Flowerdew, J and Peacock,M. 2001. The EAP curriculum: Issues, methods, and challenges in Flowerdew, $\mathrm{J}$ and Peacock,M (Eds) Issues in EAP. A preliminary perspective. UK.Cambridge University Press

Graddol, D. 1997. The Future of English. London: British Council

Haque, S. M. F. \& Maniruzaman, M. 1999. Attitudinal and Motivational Impact on EFL Proficiency of Undergraduates: A Further Investigation. The Dhaka University Studies, pp. 65-87.

Harvey, D. 1990. The condition of postmodernity. Oxford, England, Blackwell.

Hutchinson,T.and Waters,A. 1987 English for specific purposes Cambridge: Cambridge University Press.

Jordan, R. 1997. English for academic purposes. Cambridge: Cambridge University Press.

Khan, R. 2000.The English foundation course at Dhaka University: An evaluation. The Dhaka University studies, Part A, 57(1), 77-110.

Kennedy, C. et. al. 2001. Sociolinguistics, Centre for English Language studies, Birmingham.

Manivannan, G. 2006. The importance of the English Language. Retrieved April 6, 2009, from http://www.usingenglish.com/teachers/ articles/importance-english-language.html

Munby, J.1978. Communicative syllabus design. Cambridge: Cambridge University Press.

Nunan, D. 1999. Second Language Teaching \& Learning. Boston: Heinle \& Heinle publishers.

Phillipson, R. \& Skutnabb-Kangas, T. 1999. Englishization: One dimension of globalization. In D.Graddol \& U. H.Meinhof (Eds.) English in a changing world. Oxford, England. Catchline. 19-36

Qader, D. 1999:187 Students' Perception of difficulty in English courses in ELTIP International Conference: National and regional issues in English language teaching: International; Perspectives: Collected Papers. Published by National Curriculum and Textbook Board and The British Council Dhaka Bangladesh

Rahman, A. 2007. The History and Policy of English Education in Bangladesh. In The Histories and Policies of English Education in Asia. (Ed) Asia TEFL Series I (205-231) Cobblestone Austin TX

Vol. 2 No. 4, August 2009 
Rea-Dickins,P. and Germaine,K.P.1998(Eds) Managing evaluation and innovation in language teaching: building bridges. England: Longman Ltd.

Robinson, P, 1991. ESP today. Hemel Hempstead: Prentice Hall.

Tsui, A. B. M. \& Tollefson, J. W. 2007. Language policy and the construction of National Cultural identity. In A. B. M. Tsui \& J. W. Tollefson (Eds.) Language, Policy, Culture, and Identity in Asian Contexts. Lawrence Erlbaum Mahwah N.J. 1-24.

Tuckman, B. W. 1985. Evaluating instructional programs. ( $2^{\text {nd }}$ ed.) Massachusetts, USA; Allyn \& Bacon, Inc.

Widdowson, H. G. 1984. Learning Purpose and Language Use. Oxford: Oxford University Press.

Weir,C. and Roberts, J.1994 Evaluation in ELT Oxford, UK. Blackwell Publishers

Zhu, W. \& Flaitz, J. 2005 Using Focus group methodology to understand International students' academic needs: a comparison of perspectives. TESL- EJ Vol.8 No. 4 